\title{
IMPROVING STUDENT'S READING COMPREHENSION THROUGH ENGLISH SHORT STORY AT ELEVENTH GRADE OF SMAS NU CENTINI LAREN LAMONGAN
}

\author{
Zanuba Arifah Khofshoh ${ }^{1}$, Moch. Arifin ${ }^{2}$ \\ ${ }^{1,2}$ Billfath University of Lamongan \\ ${ }^{1}$ zenyarifah09@yahoo.com, ${ }^{2}$ moharifin957@gmail.com
}

\begin{abstract}
The focus of this teaching and learning activity is to improve students' reading comprehension through English short stories in eleventh grade students of SMAS NU Centini Laren Lamongan. Utilizing the existence of English short stories as a medium is expected to make a positive contribution to students through their characteristics that make readers feel happy. This research is a Classroom Action Research which is carried out by following John Elliot's model research procedures which include planning, action, observation, reflection or evaluation. The research was carried out in the eleventh class of SMAS NU Centini Laren Lamongan for the academic year 2019-2020 even semester totaling 50 students. The results showed that before being given learning using short story books in English, the average value of reading comprehension was $56(8 \%)$ in the very low category. After learning reading comprehension was carried out using English short story book media in the first cycle the average value of students 'reading comprehension increased to 67 (38\%), still in the moderate category, and learning was carried out in the second cycle the students' reading comprehension ability increased the average score. and a percentage of $77(86 \%)$ with a very high category. By using this method, there was a fairly good increase for the students of SMAS NU Centini Laren Lamongan. In addition, other results obtained were students easier to absorb and understand English learning material and this activity was also the starting point for other activities.
\end{abstract}

Keywords: Reading Comprehension, Short Story, CAR

\section{INTRODUCTION}

The goal of achievement in learning English as stated in the curriculum needs a support of all components involved in the learning process in schools. The goal can be achieved through reading. The role of reading is important for the development of knowledge. Many readers do not understand the meaning or information contained in the writing they read. This difficulty also occurs to the students at school, one of it is in English lessons. If you pay attention to the difficulties faced and the solutions needed to overcome them, it is necessary to make efforts to improve students' reading comprehension skills, especially in learning English.

The reading ability of students at SMAS NU Centini Laren Lamongan can be seen from the results of English score in the second semester in academic year 2019-2020, eleventh grade students of SMAS NU Centini Laren Lamongan from the four competences of listening, speaking, reading, and writing show that reading comprehension is very weak. There is no motivation from the students to practice their reading skills, especially reading English texts.

Reading comprehension (reading for understanding) according to Tarigan in (Yunus, 2014) is a type of reading to understand literary standards or norms, research criticism, written drama, and fictional patterns in an effort to gain understanding of the text, the reader uses certain 
strategies . Reading comprehension is a process in understanding the content of reading, so, we need a solution as a solution that at least it can reduce the students' difficulty in reading various kinds of text books in English.

Through the results of the first analysis and the questionnaire on reading interest and habits, an improvement in reading comprehension was made to the students of SMAS NU Centini Laren Lamongan. The main problem that needs attention is that students 'interest in reading English texts is still very low, the students' general English learning outcomes also show low score and it still below the minimum completeness criteria (KKM) at SMAS NU Centini Laren Lamongan. In learning English process, the ability of reading comprehension is an important variable that influences the achievement of learning outcomes according to the KKM of English lessons at SMAS NU Centini Laren Lamongan.

English short story book media can be used to improve students' reading skills. The existence of short story books as a media is expected to make a positive contribution to students through its characteristics that make readers feel happy. The students' interest in stories gives meaning to the need for the use of English short story books for learners. The use of short story book media is expected to help students develop language skills, arts, and assist students in interpreting and recalling the stories in them. In the field of literature, short story book media can encourage students to read, build vocabulary, and provide guidance and train students to express themselves with the help of character forms in short stories.

The results of research conducted by (Puspitorini et al., 2014) entitled "Use of pictorial short story media in Science Learning to Increase Motivation and Cognitive and Affective Learning Outcomes" showed that the use of pictorial short story media in science learning can increase students' learning motivation with a score of equal to 0.55 (moderate), cognitive learning outcomes gain a score of 0.42 (moderate), and improving affective learning outcomes in gain a score of 0.34 (moderate). The results of the difference test between before and after the treatment showed that there were differences in both learning motivation, cognitive learning outcomes and affective learning outcomes.

The research conducted by (Prasetyono et al., 2015) about "The Effect of Using pictorial short story media to the improvement of History Learning Outcomes" shows that there is a significant effect and the magnitude of the effect of applying pictorial short story media for about 0.61 . Based on the relevant research results, the use of learning short story book media in this study is an effort to improve students' reading comprehension skills. The short story book media is used as a learning tool because the short story book media with pictures is a popular book from children to adulthood.

The focus of the problem in this classroom action research is "How to improve understanding ability to read short stories in English for eleventh grade students of SMAS NU Centini Laren Lamongan students?" The aim of this study is to improve the students' comprehension of reading English short stories in eleventh students of SMAS NU Centini Laren Lamongan.

This classroom action research is expected to be useful for education, especially for (1) students, the short stories media for learning in English both independently and cooperatively are expected to improve reading comprehension skills, especially in learning English; (2) teachers, as an alternative learning media in teaching, especially in teaching English; and (3) schools, as an inspiration and reference to improve the quality of learning, especially in English subjects. 
Students should be accustomed to read and look for examples of concrete text, as well as new experiences so that they become trained and happy in reading, especially in English texts. The teacher as a facilitator can make students more independent in learning, teachers are more skilled and able to use learning methods and media because it has been proved that using learning methods and media can improve students' reading comprehension skills, especially in learning English. Schools should require teachers in every class to use learning media as an alternative to improve students' learning outcomes in XI students of SMAS NU Centini Laren Lamongan.

\section{METHOD}

This research is a classroom action research (Classroom Action Research) which is carried out by following the John Elliot model research procedures which include planning, action, observation, reflection. Classroom action research is a scientific research activity that is carried out rationally, systematically and empirically reflective of various actions taken by teachers or lecturers (teaching staff), collaboration (research team) as well as authorss, from the formulation of a plan to an assessment of real action in the classroom in the form of learning activities, to improve and to increase the conditions of learning carried out by (Iskandar, 2012).

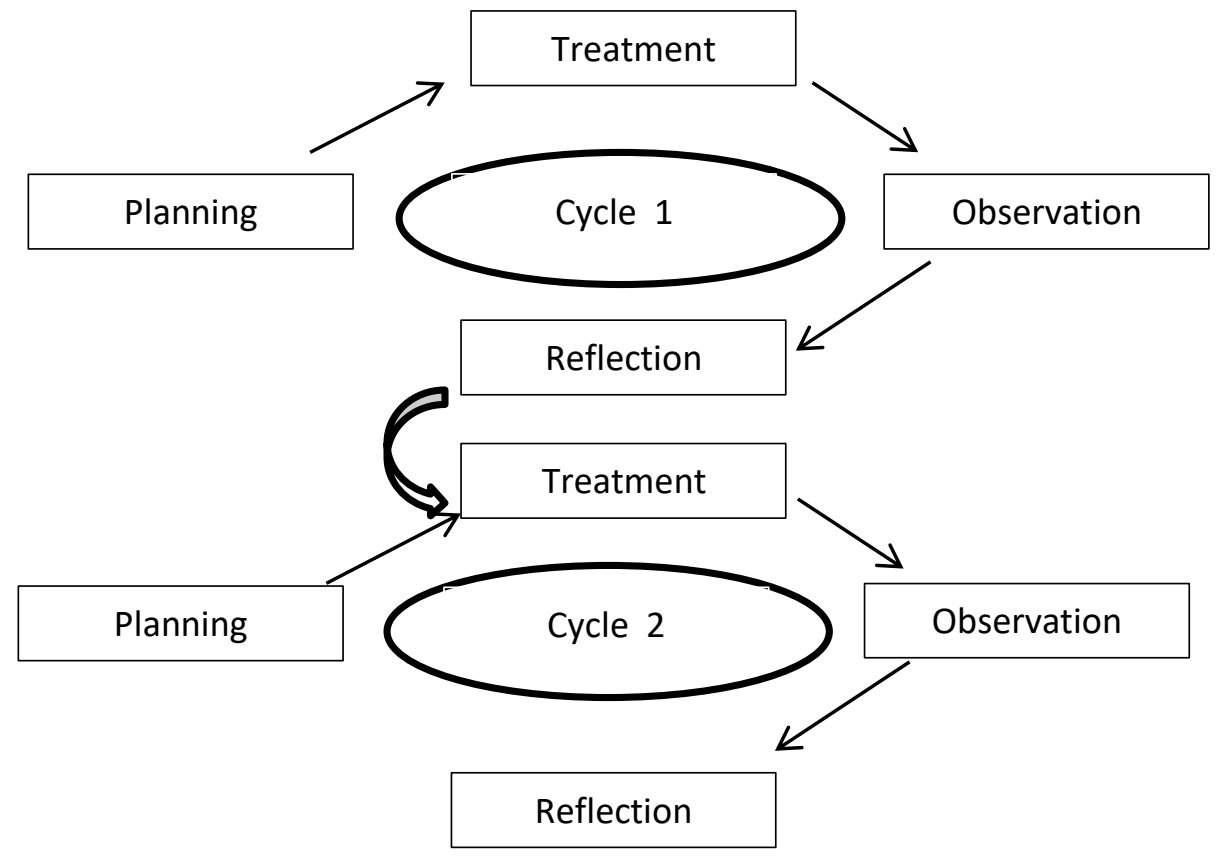

Figure 1. Classroom Action Reasearch from John Elliot model.

This research was conducted by collaborating with the English teacher at SMAS NU Centini Laren Lamongan. Each cycle is carried out based on the changes that occur in students as designed on the factors being investigated (student factors), to determine the ability to understand the contents of English reading students of class XI SMAS NU Centini Laren Lamongan are given a preliminary study without being given a method English short story media

Furthermore, in each cycle during learning, students are given treatment, namely learning reading comprehension skills by using English short story media. In the first cycle, the short stories used in English are short stories with the theme of legend, fable and myth. The second 
cycle of short stories in English that is used is short stories in English with the theme of teenagers life such as true love, first love and friendship. The English short story media used is short story learning media which is designed and developed through research and validation test, language, and contents experts of media.

Learning English reading comprehension using short story media was carried out in two cycles, four times meeting. The allocation time used for each cycle is $2 \times 40$ minutes each meeting. If the results of the second cycle test are deemed incomplete, the research will continue to the next cycle.

The indicator of success in this classroom action research refers to the Minimum Completeness Criteria (KKM) in English as set by SMAS NU Centini Laren Lamongan, it is about 70 as individual completeness. The increase value of the students' reading comprehension reading success classically reaches $\geq 75 \%$ of students who get score $\geq 65$.

This classroom action research was carried out through three cycles to see and to improve English learning. The subjects of this study were 11th grade students at SMAS NU Centini Laren Lamongan in the academic year 2019-2020 odd semester in January - June 2020. The research subjects were taken from 50 students of eleventh students at SMAS NU Centini Laren Lamongan. Authorss chose class XI because it can be seen from the low learning outcomes of English, especially in reading learning, obtained an average value of 56 with $8 \%$ completeness. (Source: document of class XI student learning outcomes of SMAS NU Centini Laren Lamongan for the 2019-2020 academic year). According to Arikunto (2006: 2-3) states that the research Classroom action is an examination of learning activities in the form of an intentional action that occurs in a class simultaneously.

Table 1: Table of Treatment

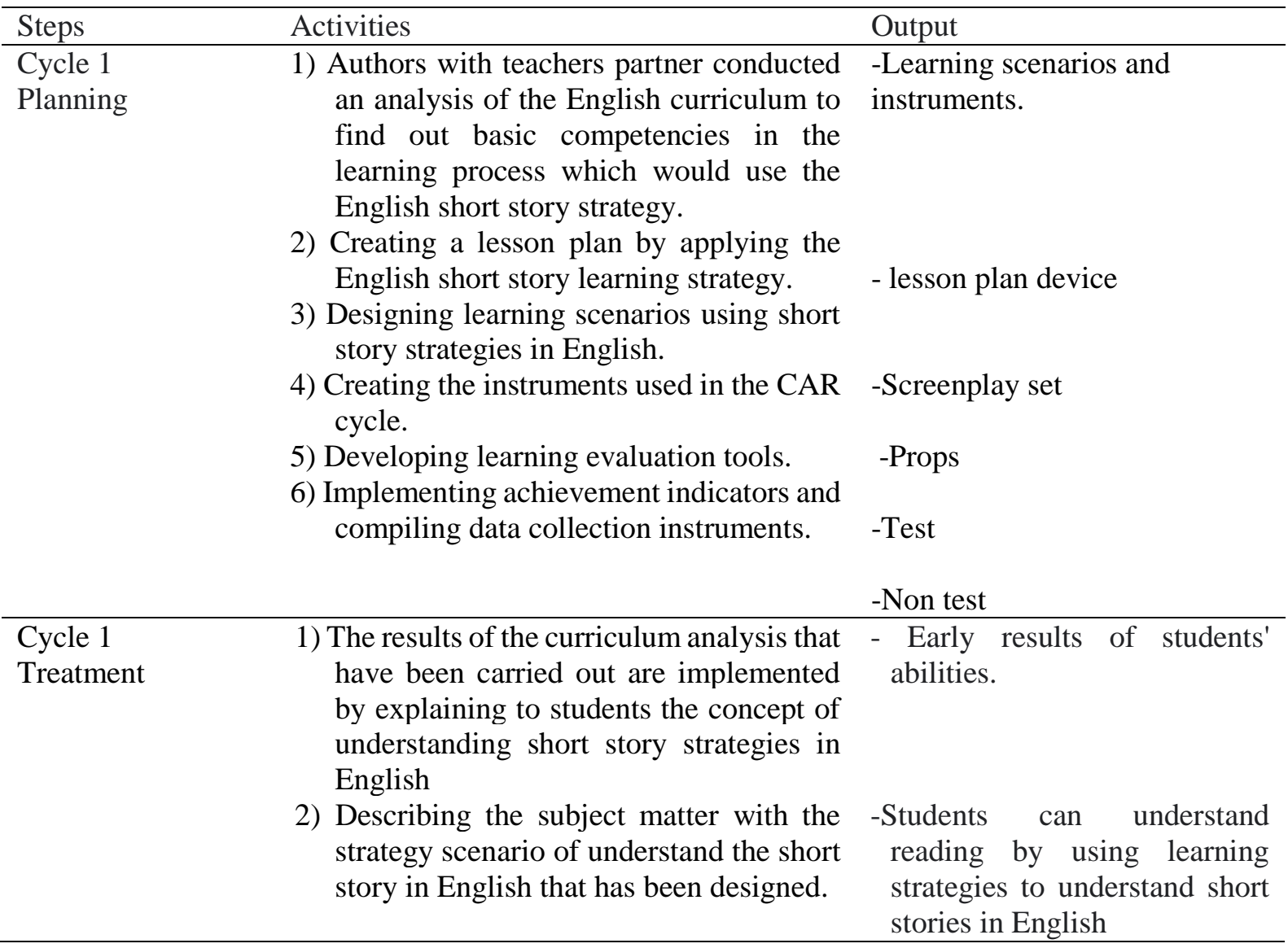


3) Based on the number of students were 50 students, the teacher divided into 7 groups with details of groups 1 to 6 consisting of 7 students and groups 7 consisting of 8 students.

4) Each group mentions the predicted title / picture of the short story in English that has been prepared by the teacher and authors.

5) Each group mentions the predicted outcome of their discussion based on the title / picture of the short story in English provided by the teacher and authors.

6) The subject matter is delivered using a scenario that has been designed.

7) Students are given the opportunity to read and understand the short stories in English that have been provided while adjusting whether the predictions of understanding they mention are appropriate or close to the titles / pictures of short stories in English that they have previously predicted. Students are asked to read the short story reading in English again while answering the reading questions and determining the type of text (genre of the text) and the purpose of the text.

8) The teacher and students discuss the results of their work together with the correct answers and make conclusions on short stories in English.

9) At the end of the action, the teacher gave a quiz related to the material that had been given.

10) The type of data collected was in the form of test / quiz results, and student behavior / activity while studying in groups.
-Divide students into groups

Students are able to predict correctly

-Students match prediction results with reading

-delivering material to the students according to the learning scenario.

-Students read silently while understanding short stories in English then match their understanding predictions.

-Answer short story reading questions in English

-Discussing student work and make conclusions of the material

-Post- test

-Test results

\footnotetext{
Cycle 1

1) Teaching and learning activities.

Observation

2) The activeness of students in group discussions.

3) The activeness of students in the reading comprehension process

4) The students' ability to express their predictions and understanding of the reading in English.

The instruments used by authorss in the observation were in the form of quiz results, observation sheets and field notes.
}

-Learning outcomes or data

was analyzed for reflection

- Students' activeness 


\begin{tabular}{ll}
\hline Cycle 1 & In this reflection stage, the authors with the -The scenario has been revised. \\
Reflection & teacher partner evaluated the teaching and \\
& learning process by using short story \\
understanding in English & If in this cycle the learning outcomes do not -It turns out that in cycle I the \\
& reach the indicator of the success of the learning outcomes have not \\
authors, then this research action is been maximized, so it is \\
continued in a cycle with the same research continued to cycle II \\
procedures. etc
\end{tabular}

During the implementation of the action, the teacher as the implementer of the action intervention refers to the program that had been prepared and agreed wih the partner. Class situations or other factors that can affect deviations from classroom activities must be avoided so that the changes that arise are actually the result of deliberate action taken for improvement. Data analysis in this action research was realized by using descriptive data analysis consisting of lesson plan, implementation, results of learning activities and data from observations on the implementation of learning. Meanwhile, quantitative data is used for the use of progress in learning comprehension of English reading.

This quantitative data was analyzed using descriptive statistics with means and percentages which can be displayed through a table interpreted by qualitative descriptive.

Furthermore, qualitative data analysis is used to see the development of attitudes and cognitive skills obtained from the observation of student activeness and the results of students' reading comprehension skills during the learning process using the English short story reading comprehension strategy. For qualitative analysis, data were obtained by categorizing data grouping based on mastery level according to the existing assessment system at SMAS NU Centini Laren Lamongan.

Table 2. The Acheivement Level Category

\begin{tabular}{ccc}
\hline No & Mastery level & Category \\
\hline 1. & $\geq 81$ & Excellent \\
2. & $76-80$ & Good \\
3. & $70-75$ & Average \\
4. & $66-69$ & Low \\
5. & $\leq 65$ & Very low \\
\hline
\end{tabular}

To analyse quantitative data obtained from students' test can be seen as follow:

$$
\text { Score }=\frac{\text { Number of students } \times 100}{\text { Number of test }}
$$

Range:

$\mathrm{A}=\geq 81 \quad=$ Excellent (they can understand and answer the questions correctly) 
$\mathrm{B}=76-80=$ Good (they can understand and answer the questions well)

$\mathrm{C}=70-79=$ Average (they can understand enough and answer the questions correctly)

$\mathrm{D}=66-69=$ Rendah (they have low understanding and answer questions correctly)

$\mathrm{E}=\leq 65=$ Very low (they cannot understand and answer the question correctly)

Table 3. The Result of Pre-Test

\begin{tabular}{cccc}
\hline No & Category & $\begin{array}{c}\text { Number of } \\
\text { students }\end{array}$ & Pecentage \\
\hline 1 & Excellent $(\geq 81)$ & - & - \\
2 & Good $(76-80)$ & 1 & 6 \\
3 & Average $(70-75)$ & 3 & 14 \\
4 & Low $(66-69)$ & 7 & 78 \\
5 & Very low $(\leq 65)$ & 39 & $\mathbf{1 0 0}$ \\
\hline
\end{tabular}

The level of achievement in this pre-test can be said that the level of mastery of reading comprehension possessed by the eleventh grade students of SMAS NU Centini Laren Lamongan was still very low, it was $8 \%$ or only 4 students from 50 students who got score $\geq$ 70 .

\section{RESULTS AND DISCUSSION}

\section{Results}

This research was conducted by collaborating with the English teacher at SMAS NU Centini Laren Lamongan. Each cycle wass carried out in accordance with changes that occur in students as designed on the factors being investigated (student factors), to determine the ability to understand the contents of English reading, students of class XI SMAS NU Centini Laren Lamongan were given a preliminary study without a reading method using English short story media.

Furthermore, in each cycle during learning, students are given treatment, namely learning reading comprehension skills using English short story media. In the first cycle, the short stories used in English are short stories with the theme of legend, fable and myth. The second cycle of short stories in English that is used is short stories in English with the theme of teenagers life such as true love, first love and friendship. The short story media in English used is short story learning media which was designed and developed through research and validation test by media, language, and contents experts

The results obtained above are in line with the discussion about learning using English romantic short story media and have been discussed by many authors as done by (Retno (Puspitorini et al., 2014) entitled "The Use of Comic Media in Science Learning to Increase Motivation and Cognitive and Affective Learning Outcomes ".

The result of this study was also in accordance with the research of (Prasetyono et al., 2015) concerning "The Effect of Comic Media Use on the Improvement of History Learning Outcomes", it is found that there is a significant effect and the magnitude of the influence of 
the application of comic media is 0.61 . The Conclusion From the results of the research and discussion was concluded that learning to read English comprehension by using English short story media can improve reading comprehension skills of class XI students of SMAS NU Centini Laren Lamongan.

1. Data Calculation of Pre-Test achievement Results of Reading Comprehension Ability, the authors and partner teacher at the beginning of the study made a plan and made treatment on reading comprehension in reading learning for class XI students of SMAS NU Centini Laren Lamongan. As a first step, students were given a pre-test to see their early abilities. From the test results, it was obtained that the overall score of the students was 2818 with an average score of 56 This average acquisition was still low from the expected completeness value was $\geq 70$. The highest score obtained by students was 76 by 1 student, while the lowest score obtained by students were 34 . Or if it was seen from the percentage of student learning outcomes it can be concluded that $92 \%$ (46 people) of students have not met the standard value $\geq 70$. Only 4 students or $8 \%$ have reached the standard of mastery of reading comprehension. The quantitative analysis of the students' pre-test results can be seen in Table 3. below. only 4 out of 50 students scored $\geq 70$.

2. Data Calculation of the Improvement of Students' Reading Comprehension Ability in Cycle I and Cycle II Students' learning result after being given action in cycle I increased with an average score of 67. This result was better than the pre-test. However, they have not yet reached the predetermined completeness indicator, only 18 students or $38 \%$ of the total number of students stated that they had reached a value of $\geq 70$. This result was still lack, therefore it was necessary to make improvements so that these results can actually reach the predetermined target. The quantitative analysis of student learning outcomes from the first cycle can be seen in Table 4 .

Table 4. Reading Understanding Skills Analysis In Cycle I

\begin{tabular}{llcc}
\hline No & Categori & Number of students & Persentage \\
\hline 1 & Excellent $(\geq 81)$ & 1 & 2 \\
2 & Good $(76-80)$ & 6 & 12 \\
3 & Average $(70-75)$ & 12 & 24 \\
4 & Low $(66-69)$ & 11 & 22 \\
5 & Very Low $(\leq 65)$ & 20 & 40 \\
\hline & Total & 50 & 100 \\
\hline
\end{tabular}

From table 4. above, it can be seen from 50 students that 1 student wass very good, 6 students got good predicate, 12 students were moderate. And there were 11 students who had low predicate and 20 students who had very low predicate. From table 4 it can be concluded that there were $38 \%$ of students who get a score of $\geq 70$.

\section{Cycle 1}

Based on the expected learning outcomes by implementing the English short story reading comprehension strategy, it showed the expected value when compared to the pretest learning outcomes, even though it had not reached the Minimum standard value or KKM set $\geq 70$.

Based on the data obtained in the first cycle and the obstacles met in the class, the authors and observer held a discussion and decided to continue the treatment in the second cycle. The implementation of this second cycle is focused on improving the results of the action by improving the implementation of the actions that were obstacles in the first cycle. 
The reason the authorss continued this action to the second cycle was due to the obstacles faced by students during the treatment including: (1) students still felt unfamiliar with learning situations that were different from usual. (2) there were still students didn't want to read understand the text caused by their inability to understand the words in the text. (3) the use of time had not been fully effective. (4) the students' interest did not seem that enthusiastic.

After corrective action was taken in cycle II, based on observations made by teacher partner (observers), it can said that the students' reading understanding increased, from 50 students there were 10 (20\%) who received very good predicate, 17 (34\%) with good predicate and 16 $(32 \%)$ students with moderate predicate. So, based on the total percentage of 50 students, there were $86 \%$ of students who had reached a value of $\geq 70$.

Based on these data, this study had achieved the indicators of the success, if students obtain a reading comprehension ability value $\geq 70$. For more details, look at Table 5 .

Tabel 5. Analysis of Reading Understanding Ability Observation In Cycle Ii

\begin{tabular}{llcl}
\hline No & Categori & Number of studentstudents & Persentase \\
\hline 1 & Excellent $(\geq 81)$ & 10 & 20 \\
2 & Good $(76-80)$ & 17 & $34 \mid$ \\
3 & Average $(70-75)$ & 16 & 32 \\
4 & Low $(66-69)$ & 5 & 10 \\
5 & Very low $(\leq 65)$ & 2 & 4 \\
\hline & Total & 50 & 100 \\
\hline
\end{tabular}

Based on table 5 above, there were improvement of students' reading understanding. From 50 students' there were 10 students got excellent predicate, there were 17 students got good predicate, 16 students got average predicate, there were only 5 students got low predicate, and 2 students got very low predicate. In this cycle the total students who got $\geq 70$ were $86 \%$. Based on the data, it indicated that the achievement success was achieved.

\section{Cycle II}

In the chart bar, it can be seen that the students' reading comprehension ability in cycle II. For the category of very good, good and moderate scores, the second cycle was higher than the first cycle, while for the low and very low score categories, the second cycle was lower than the first cycle. This showed the progress that the students made in the second cycle exceeded the first cycle.

Data Calculation for Increasing Student Activeness in cycle I and Cycle II increase in cycle I. from 50 students, there were 30 active students or about $60 \%$ of students who were active from the activeness completeness score, about $\geq 70$. The value of student activeness can be seen in Table 6. Below:

Tabel 6. Analysis of Activeness Observation In Cycle I

\begin{tabular}{llcl}
\hline No & Category & Number of students & Persentage \\
\hline 1 & Excellent & 8 & 16 \\
2 & Good & 12 & 24 \\
3 & Average & 18 & 36 \\
4 & Low & 8 & 16 \\
5 & Very low & 4 & 8 \\
\hline & Total & 50 & 100 \\
\hline
\end{tabular}


From table 6 above, it can be seen that from 50 students, there were 8 students who received the very good predicate, 12 students received the good predicate, 18 students received moderate predicate. And there were 8 students with low predicate and 4 students with very low predicate. From this table it can be concluded that there were $76 \%$ of students who were active.

\section{Cycle II}

The level of student activity, students seems quite active and communicative in responding to learning process. Furthermore, the level of student activeness also increased from the previous cycle, from 50 students, there were $10(20 \%)$ students with very good predicate, $18(36 \%)$ students with good predicate and $16(32 \%)$ students with moderate predicate. Overall, the total number of students who were active in this second cycle was $88 \%$.

Table 7. An Analisis of Activeness Observasi in Cycle Ii

\begin{tabular}{llcl} 
No & Category & Number of the students & Persentage \\
\hline 1 & Excellent & 10 & 20 \\
2 & Good & 18 & 36 \\
3 & Average & 16 & 32 \\
4 & Low & 4 & 8 \\
5 & Very low & 2 & 4 \\
\hline & Total & 50 & 100 \\
\hline
\end{tabular}

From table 7 above, it can be seen that from 50 students, there were 10 students who received the very good predicate, 18 students received the good predicate, 16 students received moderate predicate. And there were 4 students who had low predicate and 2 students who had very low predicate. From this table it can be concluded that there were $88 \%$ of students who were active.

In the table above, it can be seen that the student activity were increased in the second cycle when compared to the first cycle. For the category of very good, good and moderate assessment, the second cycle was higher than the first cycle. Meanwhile, for the very low category, the second cycle is lower than the first cycle

There was an increase in student learning outcomes. It can be explained that students who got score $\geq 70$ were $88 \%$ of the total number of students. This means that they had achieved success according to the indicators, students were successful in learning if the student scored at least 70 and the action stoped when at least $80 \%$ of the students in the class have scored $\geq 70$. Based on these indicators, the authors and the observer decideed not to continue the treatment on the next cycle.

In this second cycle, based on the expected learning outcomes by implementing the English short story reading comprehension strategy produced a more satisfactory value when compared to the learning outcomes in cycle I, which have reached the standard value or KKM set $\geq 70$ as well as the level of activity students, students looked quite active and communicative in learning.

The increasing mastery of students' English reading comprehension starting from the implementation of the Pre-Test to the end of the activity by final test in each cycle I and cycle II, it can be explained that the level of completeness of all is $86 \%$ from 50 students have completed learning reading comprehension through strategies for reading comprehension of short stories in English, and the results of this improvement are more clearly seen in Table 8. 
Tabel 8. During Cycle Treatment

\begin{tabular}{llll}
\hline No & Categori & Number of students & Persentage \\
\hline 1 & Pre-Test & 4 & 8 \\
2 & Siklus I & 19 & 38 \\
3 & Siklus II & 43 & 86 \\
\hline
\end{tabular}

\section{Discussion}

From the results described in each cycle above, it was evident that learning reading comprehension using English short story reading comprehension strategies can improve students' reading comprehension.

The learning strategy for reading comprehension in English by using short stories is beneficial for students as one of the learning strategies for reading comprehension which is very appropriate and attractive to students because this strategy is very attractive to students' interest and attention when students are required to be active in predicting the title / image designated by the teacher who can expressed through a sentence or word. After that, students are directed to the silent reading activity of the reading text while matching their prediction results with the text they read. In this activity, students carried out scanning activities. Furthermore, when students are asked reading questions, students do reading activities by scanning and skimming.

Meanwhile, the description of students' activeness towards learning by using the learning strategy of reading comprehension of short stories in English. Based on the results of observations made by partner teachers (observers), the learning process in both cycle I and cycle II, especially in cycle II, experienced a significant increase in activity. The activeness and ability to understand the text have increased and it is no longer rigid, this can be seen from their awkwardness in expressing their prediction results. This is in accordance with what was stated by (Slavin, 1999) which states that students will be more active in finding and understanding difficult concepts if they can discuss them with their friends. Based on the results of observations, the value of learning outcomes, namely the value of reading comprehension and the value of student activity, can be concluded as follows:

1. The learning strategy of reading comprehension oby using short stories in English is very beneficial for students to increase students' interest and activeness in learning reading comprehension, this is shown from the results of high student learning outcomes.

2. Based on the hypothesis of learning strategies for reading comprehension by using short stories in English, if the level of student activity is high, the level of student understanding will be high, or if the level of reading comprehension of students is high, the level of student activity will automatically be high. However, it is based on the findings of authorss in the field that this is completely imprecise because the skills being tested are reading comprehension skills. Maybe students are a bit quiet but have a high level of understanding of the reading so that these students can understand and answer reading questions or tests with satisfactory results, while there were students who have high levels of activity but have low reading comprehension levels

3. Student motivation in learning English after using the learning strategy of reading comprehension using short stories in English is high.

4. Classroom action programs for students are very necessary to improve student learning outcomes and activeness in learning. 


\section{CONCLUSION}

First, English learning activities are applied with the learning strategy of reading comprehension using short stories in English and had succeeded in increasing student activity in learning. This is known based on observation data which showed an increase in student activity during the direct action cycle. In the first cycle there were $76 \%$ of students who were active during the learning process. Then, this number increased in the second cycle to $88 \%$ of students who were active in class. These data proved that learning English by implementing the learning strategy of reading comprehension short stories in English can attract students' enthusiasm and interest to be active in participating in lessons, especially in reading skills in class.

Second, learning English activities by implementing a reading comprehension strategy of reading short stories in English can improve students' reading comprehension skills. This is based on data that showed an improvement in students' reading comprehension skills before and after the action. Based on the pre-test before the action, $8 \%$ of students had the ability to understand reading $\geq 70$. After the action, there was an increase, in the first cycle there were $38 \%$ of students who obtained a value of $\geq 70$. However, because this percentage did not meet the indicators of the success of the action, the second cycle was carried out. . After the second cycle was carried out, there was an increase in the students' reading comprehension ability to be $86 \%$ of students who obtained scores $\geq 70$.

Based on the result of this study, there are several suggestion for the involved parties. First, for the teachers in general, it is recommended to be able to increase their abilities and knowledge in teaching and learning activities. In particular, it is recommended that English teachers increase their learning knowledge related to the use of more varied and effective and communicative learning models and strategies. Second, schools are expected to improve the facilities in language learning, for example a proper laboratory, reference books, especially books in English in the library. Third, it is suggested to the Education Office to be more intense to provide a training to the teachers, especially a training related to the use of learning techniques or strategies. This training is very important to improve teacher's competence to accelerate the creativity, innovation and professional teachers. Fourth, students should be accustomed to read and look for concrete examples of text, as well as new experiences so that they will be trained and happy in reading, especially in English texts.Fifth, for teachers, it is better if the role as a facilitator can make students more independent in learning. Teachers are more skilled and able to use interesting learning methods and media, because it is proved that using English short story methods and media in learning reading can improve students' reading comprehension skills, especially in learning English.Sixth, a school should require teachers to use learning media as an alternative in improving student learning outcomes at SMAS NU Centini Laren Lamongan.

\section{ACKNOWLEDGMENTS}

The authors say, big thanks to Allah SWT for his blessings and a lot for health that given. By his blessing we can completing a paper entitled "Improving Students' reading comprehension through English short story at eleventh grade students of SMAS NU Centini Laren Lamongan" in preparing this paper, many parties have provided motivation, advice, and support the authors. In this wonderful change, the authors would like to appreciation to all parties. First, thanks to Ristek Dikti who has provided gran funds for the author as "Penelitian Dosen Pemula (PDP) . Second, we would like to thanks to the headmaster of SMAS NU Centini, LPM Bilfath 
Unversity, all my team in this research especially to English Education Study Program of Billfath Universyty. Finally, I would like to thanks for all those who have support and given an important role in the success of this paper which is still far from perfect, but it is hoped that it can be useful not only for authors, but also for readers. For this reason, constructive criticism and suggestions are welcome.

\section{REFERENCES}

Arends. R.I. (2004). Learning to Teach. Sixth Edition. New York: Mc Graw-Hill Companies Arikunto, S. (2009). Penelitian tindakan kelas. Jakarta: Bumi Aksara.

Bloom, B. S. (1959), Taksonomy of Educational Objectives: The Classification Of Educational Goals. Handbook I: Cognitive Domain. New York: Longman

Harmer, J. (2004). The Practice of English Language Teaching. Edinburgh: Pearson Education. Iskandar. (2012). Penelitian tindakan kelas. Jakarta: Referensi (GP Press Group).

Prasetyono, A. E., Amsia, T., \& Sri Ekwandari, Y. (2015). Pengaruh Penggunaan Media Komik Terhadap Peningkatan Hasil Belajar Sejarah. PESAGI : Jurnal Pendidikan Dan Penelitian Sejarah, 3(6).

Puspitorini, R., Prodjosantoso, A. K., Subali, B., \& Jumadi, J. (2014). Penggunaan Media Komik Dalam Pembelajaran Ipa Untuk Meningkatkan Motivasi Dan Hasil Belajar Kognitif Dan Afektif. Jurnal Cakrawala Pendidikan, 3(3), 413-420. https://doi.org/10.21831/cp.v3i3.2385

Slavin, R. (1999). Comprehensive approaches to CL.

Yunus. (2014). Optimalisasi Penerapan Model Penilaian Otentik Untuk Meningkatkan Kemampuan Membaca Pemahaman Siswa Sekolah Dasar. Tarbiya, April. 